GENDER STUDIES 20(1)/2021

\title{
sciendo
}

\subsection{8/genst-2022-0001}

\section{MURDEROUS MASCULINITIES \\ THE EARLY REPUBLIC OF CHARLES BROCKDEN BROWN'S WIELAND}

\author{
MICHAEL KELLER \\ Quincy University \\ kellemi@quincy.edu
}

\begin{abstract}
This essay examines Charles Brockden Brown's first novel, Wieland (1798), particularly as it engages and critiques gender and nationalism in the fictive treatment of familicidal murders that took place in the eighteenth century. More broadly, Brown's novel highlights the competing realities facing men and women in the early republic, as they navigated the shifting landscape of political and religious ideology in the turbulence of post-Revolutionary America. A close examination of Wieland offers a revealing glimpse into the tensions between patriarchy and femininity, republicanism and religion, and competing masculinities in the newly born republic that was limitlessly optimistic even as it was beset by national and familial violence.
\end{abstract}

Keywords: Charles Brockden Brown, Wieland, masculinities, patriarchy, familicide, sacrifice, masochism.

\section{Introduction}

There is a moment during the climax of Charles Brockden Brown's 1798 novel, Wieland, when the eponymous protagonist pauses in the midst of murdering his sister, Clara. Believing he had been commanded by God to offer his wife and children as a sacrifice, Wieland murdered them, but became convinced that God required one more sacrificial victim. However, as he is ready to strike her down, Clara points to the mysterious Carwin - rather than the Lord Himself - as the source of Wieland's command. For a moment, Wieland relents, ruefully commenting, "I have acted poorly my part in this world" (Brown, 2011, p. 166). But after only a few moments, Wieland is ready to strike again, announcing to his sister, "thy death must come. This minister is evil, but he from whom his commission was received is God" (Brown, 2011, p. 167). This moment - like the mind incorporating external sounds within a dream-is indicative of the competing realities facing men and women in the early republic, as they 


\section{GENDER STUDIES 20(1)/2021}

navigated the shifting landscape of political and religious ideology in the turbulence of postRevolutionary America. Indeed, a close examination of Wieland offers a revealing glimpse into the tensions between patriarchy and femininity, republicanism and religion, and competing masculinities in the newly born republic that was limitlessly optimistic even as it was beset by national and familial violence.

In many ways, Wieland has puzzled and frustrated literary critics for several decades now. Part of this is due to the novel's ambitious scope, which has led some critics to argue that the narrative itself does not hold together. ${ }^{1}$ The plot certainly has several moving parts. Clara Wieland's epistolary narration of her family's demise begins with a brief discussion of her father's ancestry, followed by the tale of the elder Wieland's immigration to-and ultimate prosperity in-colonial America. Following a religious conversion and an abortive attempt to evangelize Native Americans, "The cheapness of land, and the service of African slaves, which were then in general use, gave him who was poor in Europe all the advantages of wealth" (Brown, 2011, p. 11). Interestingly — and importantly_African slaves disappear from the novel after this reference, one aspect of the novel that merits more attention than it has received. Rushing past the above, Clara explains that her father marries, builds a temple, and, during a strange bout with religious melancholy, suffers fatal burns after ostensibly spontaneously combusting. The bulk of Clara's narrative, however, focuses on the inner workings of the heirs to Wieland: Theodore (who eventually receives the epithet Wieland) and his sister, our narrator, as well as their respective romantic interests, Catharine and Henry Pleyel. Clara's fascination centers on an outsider who intrudes into this utopian setting, a mysterious and criminalized Irishman named Carwin. Clara's narrative spends such a great deal of time examining Carwin's mysteries and mischief - including biloquism, imposture, and threats of sexual assault - that the introduction of Theodore Wieland as a sacrificial murderer comes as something of a shock to readers, even leading some (like Baym) to conclude that Brown chose sensationalism over aesthetic unity. Nevertheless, it is the well-liked and devout Theodore Wieland who, like the historical James Yates and other patriarchs in eighteenth-century America, becomes convinced that God has demanded an Abrahamic sacrifice in the form of his family. Clara eventually escapes his murderous intentions, though she is traumatized as the disabused Wieland kills himself in front of her, and she does not appear settled until she has escaped the United States and returned to the continent of her father's birth, where she marries Henry Pleyel.

\footnotetext{
${ }^{1}$ Nina Baym (1981), for instance, has written that, "there is a sacrifice of story line and character-hence, longterm coherence - for the sake of immediate effect. As the narrative progresses, indeed, a second plot, designed to maximize the opportunities for such effects, overtakes and ultimately obliterates the main story” (p. 88).
} 


\section{GENDER STUDIES 20(1)/2021}

Brown's "Advertisement" for the novel proclaims that the work "aims at the illustration of some important branches of the moral constitution of man" (Brown, 2011, p. 4). This tone of didacticism appears again at the end of the novel, when Clara places the blame for this familicidal trauma on Carwin, the outsider, and on her family's inability to overcome the effects of his preternatural powers: "If Wieland had framed juster notions of moral duty, and of the divine attributes; or if I had been gifted with ordinary equanimity or foresight, the doubletongued deceiver would have been baffled and repelled" (Brown, 2011, p. 181). For Carwin's part, he mentions "a lesson to mankind on the evils of credulity on the one hand, and of imposture on the other" (Brown, 2011, p. 158). However, all of these lessons prove shallow and reductive when applied to the novel as a whole. Following Brown, many critical treatments of the novel have reduced it to a novelistic version of ideological polemic - whether it is a critique of patriarchy or a patriarchal romance, a progressive critique of tradition or a regressive work of pulp fiction, an Enlightenment critique of religious zeal or a post-Puritan examination of the limits of Enlightenment reason. ${ }^{2}$ Again, as with Brown's attempts at didacticism, these (sometimes) binary approaches can be illuminating, but the novel itself still eludes their grasps.

\section{Masculinities in the early republic}

One of the foundational assumptions of this paper is that the purportedly convoluted nature of Brown's narrative reflects the abrupt and confusing changes facing members of the early republic. ${ }^{3}$ Daniel A. Cohen (1995) describes this period aptly: "Between 1780 and 1840 the early republic actually experienced an almost comprehensive social transformation...There was hardly a significant aspect of society that was not profoundly reshaped, resulting in new institutional and behavioral patterns that would continue to characterize American culture into the late twentieth century" (p. 727). One of these shifting realities was the accepted forms of masculinity inherited from European models. Michael Kimmel (2006) traces these evolving definitions of manhood in his work Manhood in America, wherein the "Genteel Patriarch" gives way to the "Self-Made Man." For the Genteel Patriarch, "an ideal inherited from Europe,"

\footnotetext{
${ }^{2}$ In reference to the latter, Edward Cahill (2021), argues, "In representing the variety of aesthetic experience for the moral improvement of his readers, Brown's novels navigate the economy of selfish and social passions and explore the viability of sensus communis in the post-Revolutionary United States" (p. 167). For substantive discussions of the other issues mentioned above, see, for example, the works of Bernard Rosenthal (1981), Leigh Eric Schmidt (2000), Amanda Emerson (2007), and Bryan Waterman (2009).

${ }^{3}$ This approach is becoming more standard. For example, Julia Stern (1997) similarly connects the plot to national instability, arguing that the novel's various plotlines "point to its author's deep misgivings about a postRevolutionary vision of communal order based on "fraternal sympathy"' (p. 29).
} 


\section{GENDER STUDIES 20(1)/2021}

"manhood meant property ownership and a benevolent patriarchal authority at home, including the moral instruction of his sons" (p. 13). However, given the "growing commercial and, soon, industrial society of the newly independent America, the Self-Made Man seemed to be born at the same time as his country," and this ideal, with its "mobility and insecurity," "came to dominate the American definition of manhood" in the nineteenth century (Kimmel, 2006, p. 13).

At the end of the eighteenth century, however, the new masculine American was still largely unsettled, and the Wieland lineage provides a case study of these shifts. Clara's grandfather was part of a noble ancestry in Germany, who gave up most of his material privileges when he chose a companionate marriage to a lower-class woman. Clara's father was orphaned by his parents' death and "apprenticed to a London trader, and passed seven years of mercantile servitude" (Brown, 2011, p. 9). It is during this time that the elder Wieland comes across a book by the heretical Albigenses, undergoes an intense religious conversion, and begins his trek to prosperity in America. By beginning her story with this lineage, Clara is foreshadowing the social changes and contradictory masculinities that will plague the novel. As the Genteel Patriarch, her father came from aristocratic lineage, and ruled his family benevolently: "Few men, equally sincere in their faith, were as sparing in their censures and restrictions, with respect to the conduct of others, as my father" (Brown, 2011, p. 13). As the Self-Made Man, he did not need to marry into money, instead becoming "acquainted with a woman of a meek and quiet disposition, and of slender acquirements like himself" (Brown, 2011, p. 11). Of course, this ideal of the "Self-Made Man" is itself contradictory in the Wielands' case. Clara claims that her father's "previous industry had now enabled him to dispense with personal labour, and direct attention to his own concerns," (Brown, 2011, p. 12) completely eliding her father's reliance on the labor of "African slaves" to make his fortune (Brown, 2011, p. 11). This elision forecasts the unspoken and contradictory drives and assumptions these characters have throughout the novel, as they each navigate, imperfectly, the contradictory foundations of the new republic. The father's course ends in death, as his "disobedience" (Brown, 2011, p. 13) to some divine command leads to his "inexplicable" combustion in the temple (Brown, 2011, p. 16). The father's mysterious death illustrates his failure to achieve manhood, a failure that will be inherited by his son, Theodore.

As the heir to a failed republican and Christian man, Theodore finds himself enmeshed in what Mark E. Kann (1998) calls the "complex discursive arena composed of contested ideals and consensual norms" (p. 3). On the one hand, Theodore, who will be referred to as Wieland for the remainder of this essay, appears to fulfill the nascent ideals of American manhood 


\section{GENDER STUDIES 20(1)/2021}

relatively early in the novel, as the national violence of the French and Indian War fades into the background of Utopian Mettingen. Clara writes, "Six years of uninterrupted happiness had rolled away, since my brother's marriage. The sound of war had been heard, but it was at such a distance as to enhance our enjoyment by affording objects of comparison" (Brown, 2011, p. 23). Mark E. Kann (1998) describes the "consensual core of early American manhood" as holding "the conviction that young males should mature into independent patriarchs who governed female dependents" (p. 3). In his household, Wieland stands as the clear patriarch over his wife and children, though his rule is characterized by "tenderness" (Brown, 2011, p. 23). By 1798, when Wieland was written, distrust of monarchical tyranny had trickled down into the family. Kann explains, “The Revolution's attack in favor of benevolence weakened traditional patriarchal authority and strengthened companionate norms in marriage" (1998, p. 10). It is fitting, then — and deliberately ironic, given his behavior at the end of the novel — that when Pleyel assumes Wieland can force his wife and sister to emigrate to Germany, the latter declares, "It is not my custom to exact sacrifices of this kind. I live to be their protector and friend, and not their tyrant and foe. If my wife shall deem her happiness, and that of her children, most consulted by remaining where she is, here she shall remain" (Brown, 2011, p. 37). By providing these glimpses into Wieland's management of his family, Brown depicts Wieland as the proper republican Family Man (to use Kann's term). His subsequent descent into delusions and sacrificial murder, at this point, would then seem puzzling, unless the chaos of evolving gender norms - or even the social system itself - has proven insufficient in its attempts to create order.

\section{Republican masculinities and familial precarity}

According to Kann, the development and maintenance of republican masculinity was a prevailing concern of America's founders. He writes,

\footnotetext{
Most founders feared that disorderly men threatened to destroy liberty by unleashing the twin evils of mob anarchy and demagogic tyranny. Accordingly, they confused much of their intellectual and political energy on encouraging men to defend liberty and show great restraint while exercising it...Meanwhile, most founders believed that men were more apt to defend liberty and exercise it with restraint when courting, betrothed, or wed to respectable women (1998, p. 27).
}

For much of this novel, the process of channeling potentially disruptive psycho-sexual energy into marriage works for Wieland and his family. His exercise of authority, like that of his father, 
allows for a peaceful existence within the structure of the family, in which all members feel safe and respected within this ostensibly benign patriarchy. Nevertheless, given the subsequent demise of the Wieland family, this structural organization of the family cannot withstand the subversive intrusions that are to come. Rather, as Carwin's entrance into the narrative will prove, the republican Family Man-whose disorderly drives have been successfully channeled into familial order - is vulnerable to subversive intrusion. As Clara reflects, "Something whispered that the happiness we at present enjoyed was set on mutable foundations" (Brown, 2011, p. 45).

\subsection{Carwin}

Although Clara admits that her family was ill-prepared for Carwin's entrance, she nevertheless blames the latter for the Wielands' demise, even if it happened at the hands of her brother. She begins her description of the "sudden blast and hopeless extermination" by introducing Carwin as the "most fatal and potent of mankind" (Brown, 2011, p. 41). Significantly, even as she tries to begin this section of her narrative, she becomes frustrated at herself for the intensity of her emotions during recollection: "Shame upon my cowardly and infirm heart! Hitherto I have proceeded with some degree of composure, but now I must pause" (Brown, 2011, p. 41). While displaying an internalized disgust for disorderly feminine passions, she is also exhibiting the lasting effects of disorder that Carwin would introduce into her tale.

It is reasonable, as some critics have done, to interpret Carwin's ventriloquistic impostures as the trigger for Wieland's delusions and ultimate suicide. For example, Shirley Samuels (1996) argues, “Carwin's assumption of Catharine's voice is of course what sets off the chain of disasters in Wieland" (p. 46). However, it is long before Carwin impersonates Catharine that Clara locates the source of disorder. Instead, it is after describing her first encounter with Carwin, that "How little did I then foresee the termination of that chain, of which this may be regarded as the first link?" (Brown, 2011, p. 44). Carwin's very presence, as an outsider-or, to appropriate Kann's terms, a disorderly Bachelor-introduces chaos and destruction. In this formulation, Carwin embodies the threat posed by "men who failed to marry... and often lured men into depravity" (Kann, 1998, p. 22). Kann describes the "specter of masses of disorderly men causing chaos" that haunted the early republic. To the founders, bachelors "were marginal men who indulged passion, impulse, and avarice to foment disorder in the ranks of men as well as to seduce innocent women" $(1998$, p. 76), and their "tendency 


\section{GENDER STUDIES 20(1)/2021}

toward licentiousness intensified America's democratic distemper and invited men to abuse women" (Kann, 1998, p. 79). Through this lens, Carwin did not need to use his biloquism to undermine Wieland's instability. Rather, his mere intrusion, as a disorderly man, was destined to bring about the undoing of the ill-prepared Wieland clan. This raises an obvious question regarding Brown's treatment of early republican familial relations: is the novel revealing the inherent instability of these patriarchal structures, or merely arguing that families are vulnerable if they aren't supported institutionally (thus reinforcing the validity of benign patriarchy)? While some critics have opted for the latter interpretation ${ }^{4}$, the novel itself never provides a successful familial structure available to Americans of Clara's generation. While Clara does eventually marry her beloved Pleyel, she must do so on European soil.

\subsection{Pleyel}

If Wieland is the exemplar of the republican Family Man undone by the intrusion of the disorderly Bachelor Carwin, Pleyel straddles these two figures for much of the novel. Initially betrothed to the Baroness de Stolberg, Pleyel experiences the pull back to the European continent even as he develops a romantic attachment to Clara in Pennsylvania. His attitudes toward the women around him betray the budding patriarch protector, as he complements Clara's intelligence by denigrating his sister's: "But say not a word to Catharine. Her strength of mind is inferior to your's [sic]. She will, besides, have more reason to be startled. She is Wieland's angel" (Brown, 2011, p. 36). This continues into the previously mentioned exchange with Wieland, when he asks incredulously, "when [Catharine] knows your pleasure, will she not conform to it?" (Brown, 2011, p. 37). Pleyel's admiration for Clara's intelligence and character, while superficially progressive, are nevertheless interwoven with his presumed authority as a man.

This attitude culminates later in his fiercely prosecutory exchange with Clara, when he accuses her of planning to run away with Carwin. When Clara asks him to explain his sullen and disturbed deportment, Pleyel lashes out:

\footnotetext{
${ }^{4}$ See David Brion Davis (1957), Homicide in American Fiction: 1798-1860, where he argues that "the Wielands had been left to the guidance of their own understandings... Without the authority of tradition or of a respected father, Wieland searched for God's will and for moral certainty" (p. 92). Similarly, Shirley Samuels (1990) in "Patriarchal Violence, Federalist Panic, and Wieland," where she argues, "Wieland's message may finally be that for the family to be a haven from the excesses of radical democracy, deism, and revivalism, it must be inoculated, by way of these social institutions, at once with and against the 'outside' world" (p. 65).
} 


\section{GENDER STUDIES 20(1)/2021}

The matter-O wretch! - thus exquisitely fashioned - on whom nature seemed to have exhausted all her graces; with charms so awful and so pure! how art thou fallen! From what height fallen! A ruin so complete — so unheard of!...Is not thy effrontery impenetrable, and thy heart thoroughly cankered? O most specious, and most profligate of women! (Brown, 2011, p. 81).

Until this point in the narrative, Pleyel was the model of decency and enlightenment, so what has changed? One obvious answer is that Carwin deliberately deceived Pleyel into believing the worst about Clara. However, Brown makes it clear that Pleyel was not merely a victim of deceit, but an active participant in the corruption of his own reason. As Clara laments, "Alas! it was the fate of Clara Wieland to fall into the hands of a precipitate and inexorable judge" (Brown, 2011, p. 88). This forecasts her brother's later fratricidal attempts, and connects the process by which Wieland is deluded into murder with the humiliation doled out by her beloved Pleyel (indeed, during this confusion, Wieland refers to himself as "a judge who will profit by any pretence to acquit you" [Brown, 2011, p. 85]). In both cases, the Family Man (or FamilyMan-in-the-making) is corrupted by the workings of a disorderly bachelor.

Pleyel's character arc mirrors that of a bachelor with disorderly passions attempting to become a decent, orderly, Family Man. Brown hints at Pleyel's turbulent passions when the latter refuses to attend the rehearsal at which Clara finally plans to reveal her love for him, and his outrageous treatment of Clara shows that Pleyel has lost control of his passions-an unmanly mistake. Furthermore, Pleyel admits to the same impulsiveness that Carwin will later admit to: namely, violating Clara's privacy by reading the private thoughts recorded in her diary. Once he started reading, "I had gone thus far in error, but had no power to recede" (Brown, 2011, p. 96). Carwin's later confession follows a similar track: "I opened and found a new scope for my curiosity in your books...I cannot justify my conduct, yet my only crime was curiosity. I perused this volume with eagerness" (Brown, 2011, p. 153). Significantly, the scene that undermines Clara's virtue in Pleyel's estimation takes place, on the one hand, with Carwin making use of Clara's written secrets in his biloquistic performance, and on the other hand, Pleyel coming to believe what he hears because he, too, has pried into Clara's private life. Clara herself is absent. As Kaja Silverman (1992) writes in Male Subjectivity at the Margins, "Voyeurism has been heavily coded within Western culture as a male activity, and associated with aggression and sadism" (p. 204). As Paul Lewis (1996) writes, "The mysterious Carwin...also operates from the self-absorbed, masculine assumption that he can manipulate others, experimenting with them for his own edification and delight" (p. 173). Indeed, Clara's 
words and character become the backdrop for the interplay of competing masculinities as they both aggressively_even sadistically-objectify and humiliate a woman who embodies intelligence and virtue. Furthermore, both Carwin and Pleyel treat Clara as an object of gratification-for Carwin, an intellectual and psychosexual one (one cannot forget his blithe if dishonest declaration that he intended to rape her); for Pleyel, a romantic one (even though he had not secured her hand, and she technically had no obligation of fidelity to him). ${ }^{5}$ Clara eventually exculpates Pleyel (and even marries him), but there is a moment when she depicts clearly the latter's crime: "I cannot pardon thee, Pleyel, for this injustice. Thy understanding must be hurt. If it be not, if thy conduct was sober and deliberate, I can never forgive an outrage so unmanly, and so gross" (Brown, 2011, p. 82). As Clara is being indicted by Pleyel, the reader witnesses the indictment of Pleyel's failed masculinity.

\section{Benign patriarchy and human sacrifice}

As it has become clear in this discussion, the superficially benign masculinity of the republican patriarchy came at a dire cost for those under its supposed protection. Upon marriage, as Nancy Cott (1977) explains, women lost what little legal autonomy they previously had: "In its strictly economic aspect the traditional marriage contract resembled an indenture between master and servant. Both parties had rights and obligations. The wife (much like the servant) deserved provision and owed service and obedience" (p. 22). Linda Kerber (2000) describes the ramifications of these laws: "The husband's control of all property gave him such coercive power over the wife that she could not defy him. Instead of revising the law to remove its coercive elements, jurists simply ensured that the coerced voices would not speak" (p. 115). Theoretically, a woman should be safe if she avoided the censure reserved for women who dabbled in politics, since "Only the Republican Mother was spared this hostility" (p. 117). However, as Brown illustrates in Wieland, whether tyrannical or benign, republican marriage laid the groundwork for the tortured logic of genocidal patriarchs who committed familicide in early America, so that even Republican Womanhood was not necessarily safe.

\footnotetext{
${ }^{5}$ Pleyel's logic of possession without promise is similar to the discourse surrounding "Incels" in $21^{\text {st }}$-century America. In "Taking the Black Pill" (2021), Glace et al discuss the online phenomenon of "Slut-Shaming," wherein "Incels report an obsessive desire for sexual contact with women while simultaneously degrading women who engage in sexual activity. This communicates that women's sexual desires are shameful while men's sexual desires are worthy of respect" (p. 294). While Pleyel purports to love Clara for her mind, readers cannot help but see the sense of sexual possessiveness he displays here. Furthermore, in conceiving of himself as a relatively progressive man, Pleyel participates in the appropriation of Social Justice Language referenced by et al, as well.
} 
The inspiration for Wieland ostensibly came from the well-publicized Yates Family Murders of 1781, in which James Yates became convinced that God was commanding him to murder his family as a human sacrifice, which he proceeded to do. While this story was sensational, it was not unique. As Daniel A. Cohen (1995) describes,

\begin{abstract}
In a series of curiously clustered incidents, spaced over a period of six decades, a handful of men, loving husbands and affectionate fathers, took axes from under their beds, or off their mantelpieces, and slaughtered their wives and children. The family-killings (or familicides) occurred over a wide geographic area: in the Northeast, the South, and the Midwest...In many respects they seem to have constituted a representative cross-section of American men of the early republic. What set them apart from their neighbors were a series of appalling crimes (p. 725).
\end{abstract}

While Cohen connects this to the "profound transition" (p. 747) of family values, he clarifies that these were not, on the whole, the actions of reactionary patriarchs. Instead, "most of the family-killers were extremely receptive toward the new domestic ideals. Several were explicitly described as loving husbands and affectionate fathers" (p. 748). In the end, Cohen's diagnosis is that "Physical unsettlement, economic insecurities, and religious speculations all combined to baffle and torment them. Unable to cope with the perplexities of life in a free society, they constructed internal imperatives to evade and annul that very freedom” (p. 752). Cohen's diagnosis seems sound, but in the logic of Brown's Wieland, at least, the social disorder that gives rise to this violence is inherently patriarchal. After all, it is the patriarch, and not his wife, who designates his family of human beings a possession to be sacrificed to God.

Reacting to the turbulence in 1848 France, Victor Hugo reflected, "It is as though these great public emotions create a burning atmosphere in which private feelings seethe and boil" (qtd. in Hertz, 1983, p. 36). The explosion of familicidal violence across early America, indeed, highlights the ways in which the instabilities of the public sphere spill into the intimacies of the home. ${ }^{6}$ If Rene Girard is correct in his famous treatment of sacrificial violence, Violence and the Sacred (1972), it may not be surprising that this takes the specific form of Abrahamic sacrifice. For millennia, according to Girard, ritual sacrifice was used to hold chaos at bay: "[T]here is a common denominator that determines the efficacy of all sacrifices and that

\footnotetext{
${ }^{6}$ Shirley Samuels (1996) writes in Romances of the Republic, "In Wieland, the family is initially represented as a retreat, or 'sweet and tranquil asylum', from the intrusions of the outside world, but the distinction between home and world, radically personified by the figure of the intruding Carwin, gets blurred as the destruction seen to lurk without is discovered within (p. 56). Furthermore, Nancy J. Chodorow (2002) describes how "neo-Freudians like Fromm as well as British Independents like Fairbairn and Guntrip argued strongly, drawing upon clinical evidence, that aggression is a reaction to environmental intrusion, danger, frustration, failure of fit, depressive affect, or anxiety" (p. 240). All of these, it can be argued, contribute to Wieland's descent into homicidal madness.
} 


\section{GENDER STUDIES 20(1)/2021}

becomes increasingly apparent as the institution grows in vigor. This common denominator is internal violence---all the dissensions, rivalries, jealousies, and quarrels within the community that sacrifices are designed to suppress" $(1972$, p. 8). Moreover, "The role of sacrifice is to stem the rising tide of indiscriminate substitutions and redirect violence into 'proper' channels" (p. 10). According to Girard, human sacrifice becomes less prevalent as the judicial and penal systems in a society become more powerful and pervasive. Although violence always threatens to unleash its destructive forces, and must be held back in some way by every society, "The efficiency of our judicial solution conceals the problem" (p. 19). It seems that the early American backdrop for Brown's novel (a society supposedly more civilized than that of America's original inhabitants) would be effective at holding violence in abeyance, but the happiness experienced by the Wielands is informed by nationalistic violence: "The Indians were repulsed on the one side, and Canada was conquered on the other. Revolutions and battles, however calamitous to those who occupied the scene, contributed in some sort to our happiness, by agitating our minds with curiosity, and furnishing causes for patriotic exultation" (Brown, 2011, p. 23). Here, the national violence not only protects the utopian insulation of the Wielands, but it also underpins the psychological experiences of the characters and blurs the lines between communal and familial violence.

At a more local level, the penal system is unable to contain the violence in its midst. After his arrest, Wieland becomes convinced that more sacrificial victims are required and escapes: "Twice he has escaped from his prison. The first time, he no sooner found himself at liberty, than he hasted to Pleyel's house...His chains, and the watchfulness of his guards, were redoubled; but again, by some miracle, he restored himself to liberty" (Brown, 2011, p. 141). If the appearance of an effective justice system supplants the sacrificial management of intrinsic violence, it stands to reason that the inefficacy of that justice system could precipitate a return of the sacrificial violence it had eliminated.

There is one component of a Girardian reading, however, that remains, and that is the nature of sacrificial victims. While Wieland's choice of victims is a perversion of Girard's notion of sacrifice (which is intended to "divert that impulse" away from loved ones), Girard points out that "sacrifice is primarily an act of violence without risk of vengeance" (1972, p. 13). Therefore, Wieland's initial choice of sacrificial victims - those who cannot defend or avenge themselves, since he himself would be their avenger-displays the inherently patriarchal nature of his sacrificial violence. This is not to say the victims are insignificant to the one performing the sacrifice; indeed, Wieland initially begs the divine voice, "spare, I beseech thee, this precious life, or commission some other than her husband to perform the 


\section{GENDER STUDIES 20(1)/2021}

bloody deed" (Brown, 2011, p. 126). However, Wieland's initial victims are those who do not have legal rights in early America: a married woman and her children. Significantly, when Wieland reflects on the moment he murderer his wife, he says, "I viewed her as the mother of my babes; as my wife" (Brown, 2011, p. 127). It is in her role as mother and wife that Catharine Wieland is named as the ideal victim of human sacrifice. In the end, the sacrifices do not fulfill the social role that Girard imagines in Violence and the Sacred. Partly, this is because Wieland's mimetic performance of the familicide described in Genesis (though, eventually, rejected by Abraham's God) is a perversion of the Girardian notion of sacrifice, which should serve to reconcile warring factions within a community through the sacrifice of a scapegoat. Sacrifice should restrain, or sublimate, violence, allowing it brief expression in order to keep it from spilling out and ruining human society. Whereas James Yates, according to Daniel A. Cohen (1995), "went to his sister's early the next morning and confessed" (p. 728), Wieland's patriarchal violence threatens to continue expanding as it has from Catharine to his children, then to Clara and beyond. In the logic of Wieland, then, such human sacrifice cannot quell the violence at the heart of a destabilized patriarchal society.

\section{Masculinity, masochism, and the American Dream}

Wieland's descent into homicidal mania ensures his failure to achieve republican manhood in America. Kann (1998) describes the "grammar of manhood" established by America's founders: "Its main message was that a male worthy of self-esteem, social respect, and civic dignity achieved manly independence, family status, and governance of women by fulfilling intergenerational obligations, fixing a settled place for himself and his heirs...and helping to father a new nation" (p. 50). By ending his family line, failing to raise liberty-loving republican men, and contributing to the chaos unleashed by disorderly men, Wieland's masculinity fails spectacularly. More than this, during the exultant religious ecstasy following his murderous rampage, Wieland uses the sacrifice of his family as a source of religious virtue from which he condemns the men receiving his confession: "Think ye that malice could have urged me to this deed? Hide your audacious fronts from the scrutiny of heaven. Take refuge in some cavern unvisited by human eyes. You may deplore your wickedness or folly, but ye cannot expiate it" (Brown, 2011, p. 124). Wieland's public confession can be seen as a form of exhibitionist Christian Masochism, to use Kaja Silverman's (1992) term, in a posture that "pits [him] against the society in which he or she lives, makes of that figure a rebel, or even a revolutionary of sorts" (pp. 197-198). Even as he has murdered his wife and children, and will 


\section{GENDER STUDIES 20(1)/2021}

soon attempt to murder his sister, Wieland exposes these deeds to light as though they are nothing more than symptoms of his own martyr-like suffering. While Brown makes it clear that Wieland is deluded and maniacal, the tortured logic of Wieland's exultation is a reductio ad absurdum, a reification of ostensibly benign republican patriarchy. In a society where women are legally subsumed under the identity of their husbands, their death is primarily a loss to the patriarch.

Before Clara's final confrontation with her brother, her uncle warns her against revealing to Wieland that he has murdered his family under a delusion. While she aims to save her brother's soul, her uncle warns, "Reflect on the consequences of this error. Has he not destroyed the wife whom he loved, the children whom he idolized? What is it that enables him to bear the remembrance, but the belief that he acted as his duty enjoined? Would you rashly bereave him of this belief?" (Brown, 2011, p. 140). It is noteworthy that Clara, the intended murder victim, is being held responsible for the well-being of her attacker. In the end, Clara enlists Carwin's help to disabuse him of his delusions in order to save herself. As previously mentioned, the initial attempts are unsuccessful. However, during a second attempt Carwin projects his voice convincingly, uttering, "Man of errors! cease to cherish thy delusion: not heaven or hell, but thy senses have misled thee to commit these acts. Shake off thy phrenzy, and ascend into the rational and human. Be lunatic no longer" (Brown, 2011, p. 170). In The Sublime Object of Ideology (1989), Slavoj Zizek briefly describes the same process we see in the climax of Wieland: "The sleeper is suddenly exposed to an exterior irritation.... and to prolong his sleep he quickly, on the spot, constructs a dream: a little scene, a small story, which includes this irritating element. However, the external irritation soon becomes too strong and the subject is awakened" (p. 45). Indeed, Carwin's successful irritant awakens Wieland, who is subsequently "transformed at once into the man of sorrows!" (Brown, 2011, p. 170). Upon awakening from this delusion, Wieland proves his uncle right as he "plunged [the pen knife] to the hilt in his neck; and his life instantly escaped the stream that gushed from the wound. He was stretched at my feet; and my hands were sprinkled with his blood as he fell” (Brown, 2011, p. 171).

Wieland's awakening, necessarily, results in his death. As a performer of ritual sacrifice, he has failed. Rather than help birth the incipient republic, he has participated in the disorderly chaos that could subvert it. He has no place as a republican man. Clara, on the other hand, appears to retreat into the very patriarchal relations that led to the Wielands' demise. This can appear puzzling, since Clare evinces a strong — even proto-feminist—heroism throughout the 
novel. ${ }^{7}$ In Margaret Fuller's oft-quoted review from 1846, the great American feminist writes, "Brown... has usually placed this thinking royal mind in the body of a woman. This personage too is always feminine, both in her character and circumstances, but a conclusive proof that the term feminine is not a synonym for weak" $(1981$, p. 63).

\section{Conclusion}

It is nevertheless true that, unlike Constantia (the heroine of Ormond who leaves the world of men behind), Clara enters into the matrimonial structure that doomed her sister-inlaw. She even waits for Therese de Stolberg, the woman who (figuratively) dies and is reborn for the sake of her beloved Pleyel, before accepting Pleyel's hand. Andrew Scheiber (1991) argues that Clara "has achieved closure only by aligning herself totally with the typology of patriarchal force, and inverting the true implication of her experience" (p. 187). But there are two important qualifications to this claim. First is Scheiber's earlier point that, "As a woman trapped within this field of masculine religious power, Clara is subject to its effects without being able to participate fully in its conduct" (1991, p. 182). That is, the America of Wieland does not have space for a self-actualized woman outside of the patriarchal structures at the time. Second, Clara escapes into this matrimonial dream back on the European continent, much closer to her grandfather's noble lands than to the once-Utopian Mettingen, Pennsylvania, which imploded under the explosive tensions of early America. Finally, to return to a less frequently quoted passage from Margaret Fuller's review of Wieland, it is important to note that Fuller recognized that Brown's treatment of his heroine was not indicative of a mere obsession with abnormal psychology or a desire to gain a mesmerized readership. Rather, Fuller soberly assesses his characters thusly: "The horrors which mysteriously beset these persons, and against which, so far as outward facts go, they often strive in vain, are but a representation of those powers permitted to work in the same way throughout the affairs of this world" (1981, p. 63). Looking back at pre-Revolutionary America from the vantage point of his nascent republic, Brown was indeed exploring the "affairs of this world," particularly how the tensions of gender, authority, and national identity threatened to invoke a primal violence in the near, and uncertain, future.

\footnotetext{
${ }^{7}$ Sydney Krause (2000) points to Clara "as a woman liberated from the religio-sexist-based stereotype" (p. 367). More broadly, Fritz Fleischmann (2019) has argued, "women appear as victims and survivors, foils and collaborators, interrogators and countermodels, whose memorable humanity and strength of mind beg the question of their equality with men (p. 288).
} 


\section{GENDER STUDIES 20(1)/2021}

\section{References}

Baym, N. (1981). A Minority Reading of Wieland. In B. Rosenthal (Ed.), Critical Essays on Charles Brockden Brown (pp. 87-103). G.K. Hall \& Co.

Brown, Ch. B. (2011). Wieland and Memoirs of Carwin the Biloquist: A Norton Critical Edition. B. Waterman (Ed.). Norton.

Cahill, E. (2021). Liberty of the Imagination: Aesthetic Theory, Literary Form, and Politics in the Early United States. University of Pennsylvania Press.

Chodorow, N. J. (2002). The Enemy Outside: Thoughts on Psychodynamics of Extreme Violence with Special Attention to Men and Masculinity. In J. K. Gardiner (Ed.), Masculinity Studies \& Feminist Theory: New Directions (pp. 236-256). Columbia University Press.

Cohen, D. A. (1995). Homicidal compulsion and the conditions of freedom: the social and psychological origins of familicide in America's early republic. Journal of Social History, 28(4), 725-764.

Cott, N. F. (1977). The Bonds of Womanhood: 'Woman's Sphere' in New England, 1780-1835 (2 ${ }^{\text {nd }}$ ed.). Yale University Press.

Davis, D. B. (1957). Homicide in American Fiction: 1798-1860. Cornell University Press.

Fleischmann, F. (2019). Brown and Women's Rights. In P. Barnard, H. Emmett \& S. Shapiro (Eds.), The Oxford Handbook of Charles Brockden Brown (pp. 288-301). Oxford University Press.

Fuller, M. (1981). Papers on Literature and Art. In B. Rosenthal (Ed.), Critical Essays on Charles Brockden Brown (pp. 62-65). G.K. Hall \& Co.

Girard, R. (1977). Violence and the Sacred. P. Gregory (Trans.). The Johns Hopkins University Press.

Glace, A. M., Dover T.L., \& Zatkin, J. G. (2021). Taking the black pill: an empirical analysis of the incel. Psychology of Men \& Masculinities, 22(2), 288-297.

Hertz, N. (1983). Medusa's Head: Male Hysteria under Political Pressure. Representations, 4, $27-54$.

Kann, M. E. (1998). A Republic of Men: The American Founders, Gendered Language, and Patriarchal Politics. New York University Press.

Kerber, L. (2000). The Republican Mother and the Woman Citizen. In L. K. Kerber \& J. S. De Hart (Eds), Women's America: Refocusing the Past (5 $5^{\text {th }}$ ed.) (pp.112-120). Oxford University Press.

Kimmel, M. (2006). Manhood in America: A Cultural History (2 $2^{\text {nd }}$ ed.). Oxford University Press.

Krause, S. J. (2000). Brockden Brown's Feminism in Fact and Fiction. In K. H. Schmidt \& F. Fleischmann (Eds.), Early America Re-Explored: New Readings in Colonial, Early National, And Antebellum Culture (pp. 349-384). Peter Lang.

Lewis, P. (1996). Charles Brockden Brown and the Gendered Canon of Early American fiction. Early American Literature, 31(2), 167-188.

Samuels, S. (1980). Patriarchal Violence, Federalist Panic, and Wieland. Early American Literature, 25(1), 46-66.

Samuels, S. (1996). Romances of the Republic: Women, the Family, and Violence in the Literature of the Early American Nation. Oxford University Press.

Scheiber, A. J. (1991). “The arm lifted against me": Love, Terror, and the Construction of Gender in Wieland. Early American Literature, 26(2), 173-194.

Silverman, K. (1992). Male Subjectivity at the Margins. Routledge. 
Stern, J. A. (1997). The Plight of Feeling: Sympathy and Dissent in the Early American Novel. University of Chicago Press.

Zizek, S. (2009). The Sublime Object of Ideology (2 $2^{\text {nd }}$ ed.). Verso.

Michael KELLER is an Associate Professor of English at Quincy University, where he teaches courses in American literature, rhetoric, and literary theory. He has previously written about the poetry of John Greenleaf Whittier and Jones Very, ekphrasis in American poetry, and more recently, the intersections between race, labor, and poetic form in abolitionist and antiabolitionist writing. Currently a Fulbright Professor of English at the Universitetet i Bergen, he is devoting more time to researching the intersections between early nationalism and American literature, especially in the work of Charles Brockden Brown. 